\title{
Significance of carcinoembryonic antigen in retinoblastoma
}

\author{
ARUP DAS, ${ }^{1}$ INDRA SEKHAR ROY, ${ }^{1}$ TUSHAR K. MAITRA, ${ }^{2}$ \\ AND ASHISH KANJILAL ${ }^{2}$ \\ From the ${ }^{1}$ Regional Institute of Ophthalmology, Calcutta, and ${ }^{2}$ Kothari Centre of Gastroenterology, \\ Calcutta, India
}

SUMMARY The role of estimating the serum carcinoembryonic antigen (CEA) in the diagnosis and prognosis of retinoblastoma cases has been evaluated. Although the mean serum CEA titre in children with retinoblastoma was higher than that in control children $(p=0.01)$, the serum CEA level itself was found not to be a useful marker in the diagnosis of retinoblastoma. A significant correlation of serum CEA titre with progression or regression of the disease observed during therapy in most cases indicated that seriaı assays of serum CEA may be important in the follow-up of cases with retinoblastoma. The lower CEA values in aqueous humour and subretinal fluid from eyes with retinoblastoma than in the serum suggests that the tumour does not secrete the CEA.

The detection of tumour-associated antigens in serum or body fluids has been the subject of recent interest in the diagnosis and follow-up of malignant tumours. ${ }^{1}$ Elevated serum levels of one of these antigens, carcinoembryonic antigen (CEA), have been described in many malignant conditions, ${ }^{12}$ especially colorectal and pancreatic carcinomas, and also recently in many nonmalignant conditions. ${ }^{1}$ So far only a few studies have emphasised the role of CEA in retinoblastoma. ${ }^{34}$

In the present study we aimed to find out the usefulness of measuring the serum CEA level in the diagnosis and prognosis of retinoblastoma cases.

\section{Materials and methods}

Twelve cases of histologically proved retinoblastoma (age range 1 year 5 months to 5 years 2 months) seen at the Regional Institute of Ophthalmology, Calcutta, were included in this study. The diagnosis of retinoblastoma was made on the basis of clinical history, ocular and systemic examination, slit-lamp biomicroscopy, ophthalmoscopy, and radiography of the skull and orbits, together with estimation of lactate dehydrogenase (LDH) and the electrophoretic protein pattern of the aqueous in cases where aqueous collection was possible from the intact anterior chamber. All these cases underwent enucleation or

Correspondence to Dr I. S. Roy, Director, Regional Institute of Ophthalmology, Medical College, Calcutta 700073 , India. exenteration, and the eyeballs were subjected to histopathological examination for the confirmation of diagnosis. After operation the patients were treated with radiotherapy or chemotherapy or both depending on the histopathological extent of the tumour and assessment of any developing metastatic nodules. Cases were followed up for every month for a period of 6 months. In 3 cases gamma scan for detection of bony metastases was performed.

In 11 of these patients the serum CEA levels were estimated before enucleation or exenteration and 2 weeks after and then at intervals in selected cases. In one case no pre-enucleation value for serum CEA was available.

The sera from 10 children (age range 1 to 5 years) with congenital cataract (6), Coats's disease (2), endophthalmitis (1), and retinal detachment (1) were also collected for control serum CEA values. In selecting the control children diseases that come into the differential diagnosis of retinoblastoma were included, as this was considered to be a better control population than age-matched normal children (Felberg, personal communication, 1982).

The sera samples were stored at $-20^{\circ} \mathrm{C}$, and CEA levels were measured with a radioimmunoassay kit (Phadebas CEA PRIST, Pharmacia Diagnostics). Counting was done on a Beckman Gamma Counter (model Gamma 4000).

In addition, from 4 patients with retinoblastoma the pre-enucleation sera and aqueous specimens from 
Table 1 Serum CEA values in retinoblastoma children and control children

\begin{tabular}{|c|c|c|c|c|c|c|}
\hline \multirow[t]{2}{*}{ Diagnosis } & \multirow{2}{*}{$\begin{array}{l}\text { Total } \\
\text { no. of } \\
\text { children }\end{array}$} & \multicolumn{4}{|c|}{ No. of cases } & \multirow{2}{*}{$\begin{array}{l}\text { Mean } \\
C E A \\
\text { titre } \mu g / l\end{array}$} \\
\hline & & $0-2 \cdot 5 \mu \mathrm{g} / l$ & $2 \cdot 6-5 \cdot 0 \mu \mathrm{g} / l$ & $5 \cdot 1-10 \cdot 0 \mu g / l$ & $>10.0 \mu \mathrm{g} / \mathrm{l}$ & \\
\hline $\begin{array}{l}\text { Retinoblastoma } \\
\text { Control children }\end{array}$ & $\begin{array}{l}11 \\
10\end{array}$ & $\begin{array}{l}3 \\
5\end{array}$ & $\begin{array}{l}2 \\
5\end{array}$ & 2 & 4 & $\begin{array}{l}7 \cdot 5^{*} \\
2 \cdot 77 \dagger\end{array}$ \\
\hline
\end{tabular}

${ }^{*} \mathrm{SD}=5 \cdot 106 ; \mathrm{n}=11$.

†Congenital cataract (6), Coats's disease (2), endophthalmitis (1), retinal detachment (1). SD=1·084; $n=10$.

the enucleated eyeballs were also subjected to CEA assay. In 2 of these 4 eyes the subretinal fluid (SRF) was collected by paracentesis of the intact globe for CEA estimation. ${ }^{5}$ Aqueous humour and subretinal fluid samples were obtained with a 25-gauge needle attached to a dry tuberculin syringe. These samples were stored and processed in the same way as the serum samples.

\section{Results}

The mean serum CEA titre in children with retinoblastoma $(7 \cdot 5 \mu \mathrm{g} / \mathrm{l})$ was higher than the mean serum CEA titre in control children $(2.77 \mu \mathrm{g} / \mathrm{l})$ (Table 1$)$. While $55.5 \%$ of the retinoblastoma cases had serum CEA levels more than $5.0 \mu \mathrm{g} / \mathrm{l}$, none of the control children showed serum CEA levels above 5.0 $\mu \mathrm{g} / \mathrm{l}$.

In 5 (cases 1 to 5 ) out of 12 children the serum CEA titre dropped significantly 2 weeks after surgery, and no recurrence of metastasis was noted within 6 months in them except in one case (case 3) (Table 2). This group included 2 cases with histological evidence of optic nerve invasion, and both needed postoperative radiotherapy. In the other 6 cases (cases 6 to 11) the CEA titre continued to rise even after surgery, and these mostly included children with proptosis and metastases. The spread of the disease was reflected in the immediate rise of the postoperative serum CEA values (Table 2).

In case 7 the serum CEA level continued to rise even after surgery and chemotherapy, and the child

Table 2 Change in serum CEA values in retinoblastoma patients after therapy (surgical, radio-, or chemotherapy)

\begin{tabular}{|c|c|c|c|c|c|c|}
\hline \multirow[t]{2}{*}{ No. } & \multicolumn{2}{|c|}{ Serum $C E A(\mu g / l$} & \multirow{2}{*}{$\begin{array}{l}\text { Nature of } \\
\text { postoperative } \\
\text { therapy }\end{array}$} & \multicolumn{2}{|c|}{ Serum $C E A(\mu g / l)$} & \multirow[t]{2}{*}{ Remarks } \\
\hline & Preoperative & $\begin{array}{l}\text { Postoperative } \\
\text { (after } 2 \text { weeks } \\
\text { of surgery) }\end{array}$ & & $\begin{array}{l}\text { Postradio-/cher } \\
\text { after } 6 \text { weeks }\end{array}$ & $\begin{array}{l}\text { motherapy } \\
\text { after } 12 \text { weeks }\end{array}$ & \\
\hline 1 & $8 \cdot 60$ & $7 \cdot 80$ & - & - & - & $\begin{array}{l}\text { Leucocoria; no optic nerve infiltration; no } \\
\text { recurrence or metastases within } 6 \text { months }\end{array}$ \\
\hline 2 & $9 \cdot 20$ & $4 \cdot 50$ & Radio- & - & - & $\begin{array}{l}\text { Leucocoria; optic nerve infiltration; no recurrence } \\
\text { or metastases within } 6 \text { months }\end{array}$ \\
\hline 3 & $12 \cdot 20$ & $6 \cdot 0$ & Radio- & $7 \cdot 80$ & - & $\begin{array}{l}\text { Proptosis; optic nerve infiltration; metastases } \\
\text { appeared within } 3 \text { months }\end{array}$ \\
\hline 4 & $11 \cdot 80$ & $4 \cdot 20$ & - & - & - & $\begin{array}{l}\text { Leucocoria; no optic nerve infiltration; no } \\
\text { recurrence or metastases within } 6 \text { months }\end{array}$ \\
\hline 5 & $14 \cdot 30$ & $9 \cdot 30$ & - & - & - & $\begin{array}{l}\text { Leucocoria; no optic nerve infiltration; no } \\
\text { recurrence or metastases within } 6 \text { months }\end{array}$ \\
\hline 6 & $14 \cdot 0$ & $16 \cdot 50$ & Radio- & $6 \cdot 0$ & - & $\begin{array}{l}\text { Leucocoria; optic nerve infiltration; no recurrence } \\
\text { or metastases within } 6 \text { months }\end{array}$ \\
\hline 7 & $1 \cdot 60$ & $3 \cdot 0$ & Chemo- & $4 \cdot 0$ & - & $\begin{array}{l}\text { Massive proptosis; optic nerve infiltration; died } \\
\text { within } 3 \text { months of exenteration }\end{array}$ \\
\hline 8 & $2 \cdot 60$ & $4 \cdot 82$ & Chemo- & $2 \cdot 05$ & - & $\begin{array}{l}\text { Proptosis; optic nerve infiltration; metastases } \\
\text { present; all metastases disappeared at the end of } \\
\text { chemotherapy within } 3 \text { months }\end{array}$ \\
\hline 9 & $2 \cdot 45$ & $4 \cdot 80$ & Chemo- & $4 \cdot 48$ & $16 \cdot 90$ & $\begin{array}{l}\text { Proptosis; optic nerve infiltration; metastases } \\
\text { present; with chemotherapy metastases first } \\
\text { disappeared and again recurred after } 4 \text { months }\end{array}$ \\
\hline 10 & $3 \cdot 60$ & $4 \cdot 00$ & Radio- & - & - & $\begin{array}{l}\text { Proptosis; optic nerve infiltration; metastases } \\
\text { appeared within } 2 \text { months }\end{array}$ \\
\hline 11 & $2 \cdot 20$ & $9 \cdot 10$ & $\begin{array}{l}\text { Radio- and } \\
\text { chemo- }\end{array}$ & - & - & $\begin{array}{l}\text { Proptosis; optic nerve infiltration; metastases } \\
\text { appeared within } 3 \text { months }\end{array}$ \\
\hline 12 & Not done & $2 \cdot 40$ & Radio- & $4 \cdot 80$ & - & $\begin{array}{l}\text { Recurrence in the same orbit occurred within } 2 \\
\text { months of surgery in spite of radiotherapy }\end{array}$ \\
\hline
\end{tabular}


Table 3 Comparison of CEA values in serum and ocular fluids

\begin{tabular}{llll}
\hline $\begin{array}{l}\text { Serial } \\
\text { no. }\end{array}$ & $\begin{array}{l}\text { Serum } \\
C E A\end{array}$ & $\begin{array}{l}\text { Aqueous } \\
\text { humour } \\
\text { CEA } \mu \mathrm{g} / \mathrm{l}\end{array}$ & $\begin{array}{l}\text { Subretinal } \\
\text { fluid } C E A \\
\mu \mathrm{g} / l\end{array}$ \\
\hline 1 & $3 \cdot 10$ & $1 \cdot 50$ & $2 \cdot 20$ \\
2 & $7 \cdot 0$ & $5 \cdot 20$ & $5 \cdot 80$ \\
3 & $9 \cdot 0$ & $1 \cdot 0$ & - \\
4 & $11 \cdot 0$ & $2 \cdot 05$ & - \\
\hline
\end{tabular}

died in 3 months. In case 8 , although the CEA titre was elevated after surgery, it came down after chemotherapy, with the concurrent disappearance of metastases. In case 9 the CEA level increased after removal of the tumour but with chemotherapy, when metastases were found to disappear, there was no further rise in the CEA titre. After 4 months, when metastases again developed, there was concurrent elevation of the CEA titre. In case 12 no preoperative value for serum CEA was available, as the case was referred to us after enucleation, and when orbital recurrence occurred despite radiotherapy there was also a rise in the serum CEA titre (Table 2).

As shown in Table 3, the CA values for serum were higher than those for intraocular fluids in the small group of cases in which they were compared. The concentrations of CEA in 2 samples of subretinal fluid were almost similar to the aqueous CEA levels.

\section{Discussion}

Though in comparison with the control children the retinoblastoma cases showed a significantly higher $(p=0 \cdot 01)$ mean serum CEA value, the individual serum CEA values in $44.5 \%$ of the children with retinoblastoma overlapped the individual CEA values of the control children. Therefore the serum CEA level itself was not a significant diagnostic marker for retinoblastoma. Michelson et al. ${ }^{3}$ have made a similar observation. This limitation of the diagnostic value of the serum CEA may not be unique for retinoblastoma, since other investigators have also observed that some of the diagnosed malignant neoplastic conditions might be associated with normal serum CEA values. ${ }^{16}$

A decrease of the serum CEA titre following surgery indicates a good prognosis, as the incidence of recurrence or metastasis is low in such cases. A similar fall of the serum CEA level after surgery in other malignant conditions has been ascribed to the decrease in the tumour burden. ${ }^{7}$ However, the source of CEA is retinoblastoma is probably not the tumour, ${ }^{3}$ and so the concept of decrease in the tumour burden may not be applicable. Most of the cases in which the postoperative level of serum CEA was higher than the preoperative value developed metastasis or tumour recurrence, so that this condition indicated an unfavourable prognosis. The response with radio- or chemotherapy, if any, was also reflected in a decrease in the serum CEA level, and, if the tumour recurred after therapy, the serum CEA titre also went up. Thus from an increase in the titre of serum CEA following surgery or radio- and/or chemotherapy one can detect cases with an unfavourable prognosis. Serial serum CEA assays during therapy may help in the management of retinoblastoma cases.

The lower CEA values in SRF and aqueous compared with the serum in the present series precludes the possibility of the tumour as the source of CEA. If the CEA were secreted by the tumour, it would be released into the surrounding subretinal fluid and then to aqueous, and this would lead to higher CEA levels in SRF and aqueous than in the serum. Moreover by immunohistochemical techniques CEA could be demonstrated neither in the tumour tissue nor in culture media of the retinoblastoma tumour tissue. ${ }^{3}$

Although, apparently, CEA may not be produced by the tumour, it is possible that the release of a chemical mediator from the tumour may diffuse into the circulation and so stimulate the synthesis of CEA in other target organs. ${ }^{3}$ Even with this possibility, the tumour bulk may be controlling the synthesis of CEA indirectly through the controlled production of the chemical mediator.

We thank Dr K. N. Jalan, chief co-ordinator, Kothari Centre of Gastroenterology, Calcutta, for his kind help, and Mr E. G. P. Nair for secretarial assistance.

\section{References}

1 Freedman SO. Antigens in tumours. In: Symington T. Carter RL. eds. Scientific foundations of oncology. London: Heinemann. 1976: 509-11.

2 Gold P, Freedman SD. Demonstration of tumour specific antigens in human colonic carcinomata by immunological tolerance and absorption techniques. J Exp Med 1965; 121: 439-59.

3 Michelson JB, Felberg NT, Shields JA. Fetal antigens in retinoblastoma. Cancer 1976; 37: 719-23.

4 Gerke E. Hierholzer E, Vogel M. Hoppins W, Kuwert EK. Carcinoembryonic antigen in retinoblastomas. Albrecht von Graefes Arch Klin Ophthalmol 1978; 205: 121-7.

5 Michelson JB, Felberg NT. Shields JA, Felberg R. Subretinal fluid examination of LDH, PGI and CEA in a case of metastatic bronchogenic carcinoma of the choroid. Cancer 1978; 41: 2301-4.

6 Ravry M, Moertel CG. Schutt AJ, Go VLW. Usefulness of serial serum carcinoembryonic antigen (CEA) determinations during anticancer therapy or long term follow-up of gastrointestinal carcinoma. Cancer 1974; 34: 1230-4.

7 Shusters J, Thomson DMP, Gold P. Immunodiagnosis. In: Castro JE, ed. Immunological aspects of cancer. London: MTP Press. 1978: 298-335. 